primary atypical pneumonia, but does not cause the meningitis. Of the two remaining cases one had right-sided pneumonia and the other pharyngotracheitis.

The temporal association between cold-agglutinin-positive infection and aseptic meningoencephalitis or meningitis in the eight cases described is not definite evidence of an aetiological relation. The cases should, however, be noted in respect of the possibility of mycoplasma infection in aseptic meningoencephalitis or meningitis, especially in cases without sign of atypical pneumonia.

\section{Summary}

From January 1962 to June 1963126 patients (69 females and 57 males) with cold-agglutinin-positive infection were treated at the Stockholm Hospital for Infectious Diseases. Eight of them ( 2 females and 6 males) had aseptic meningoencephalitis or meningitis. Six of the eight patients were aged 5 to 29 years ( 75 of the total number of patients were in this age-group) and were among the 72 patients who fell ill between October 1962 and February 1963.

It is suggested that Mycoplasma pneumoniae may be a cause of aseptic meningitis.

\section{REFERENCES}

Chanock, R. M., Cook, M. K., Fox, H. H., Parrott, R. H., and Huebner, R. J. (1960) New Engl. 7. Med., 262, 648.

Kahlmeter, O. (1961). Ciba Foundation Study Group, 7, 24

Keizer, D. P. R. (1949). Maanschr. Kindergeneesk., 17, 172.

Lepow, L. L., Carver, D. H., Wright, H. T., Woods, W. A., and Robbins, F. C. (1962). New Engl. F. Med., 266, 1181.

Museteanu, C., Visinescu, D., and Museteanu, V. (1963). Stud. Cercet. Inframicrobiol., 14, 61.

Sterner, G. (1956). Ann. paediat. (Basel), 187, 321.

Ström J. (1956). Acta med. scand., 154, Suppl. No. 136.

(1962). Acta Allerg. (Kbh.), 17, 232.

(1963). Akuta infektionssiukdomar. Lund

Svedmyr, A. (1963). Arch. ges. Virusforsch., 13, 167.

Tunevall, G., Ohlson, M., Svedmyr, A., von Zeipel, G., Frisk, A., Hedlund, P., Lamberger, B., and Jernelius, H. (1963).' Acta med. scand., 174, 237.

von Zeipel, G., and Svedmyr, A. (1957). Arch. ges. Virusforsch., 7, 355.

\title{
Effect of Clofibrate and Androsterone on Hypercholesterolaemic Xanthomatosis
}

\author{
BERNARD MASON,* M.B., CH.B. ; C. BRUCE PERRY,* M.D., F.R.C.P.
}

When the claim was made that the oral administration of clofibrate in combination with androsterone (Atromid) led to a lowering of serum cholesterol in patients with hypercholesterolaemia and coronary artery disease (Oliver, 1962) it appeared desirable to determine the effect of this therapy in patients with other manifestations of hypercholesterolaemia. Seven such patients have now been treated for two years with $2 \mathrm{~g}$. of Atromid daily in three divided doses. These patients fall into four groups.

Group $A$ consisted of three male patients aged 30,40, and 46 with xanthoma tuberosum on the knees and elbows. The xanthomata had been noted for 18 months, 3 years, and 15 years respectively. The two elder patients had suffered inter-

* From the Department of Medicine, University of Bristol. mittent claudication in one leg for eight and three years respectively. All three had impalpable dorsalis pedis pulses in one or both feet. Before treatment their serum cholesterol was 460 , 325 , and $500 \mathrm{mg} . / 100 \mathrm{ml}$. respectively. These levels fell to below $250 \mathrm{mg}$. in two cases within a month of starting treatment. The other fell promptly to $300 \mathrm{mg}$. in six weeks and then fell still further to $250 \mathrm{mg}$. or below over the next three months. All have remained below $250 \mathrm{mg}$. for the rest of the two years. Total serum lipids before treatment ranged from 2.9 to $3.05 \mathrm{~g}$./ $100 \mathrm{ml}$., and after treatment from 1.35 to $1.85 \mathrm{~g}$. In all three the xanthomata have disappeared. They appeared to be diminishing three to five months after starting treatment and had completely disappeared in 11 to 13 months. The patient with the shorter history of intermittent claudication insists that he can now walk about four times as far before getting pain.

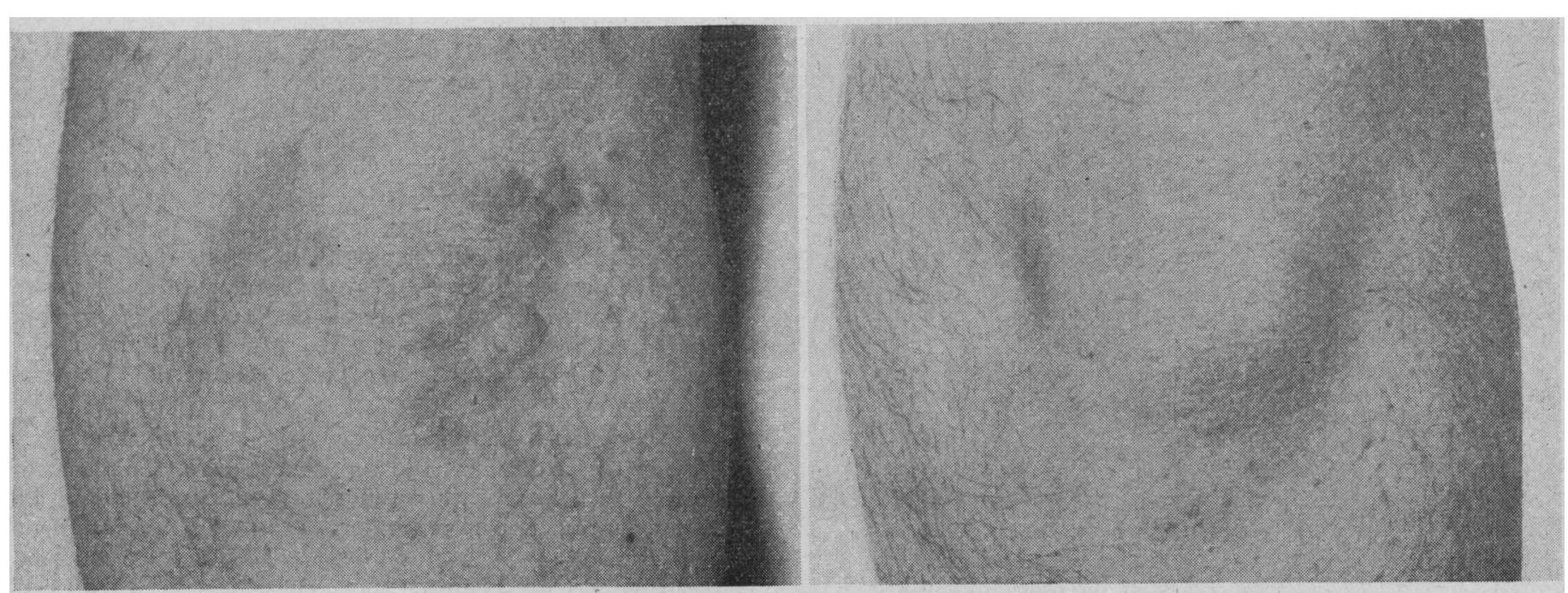

Photographs of elbow of patient in group B. Left, photograph taken on 14 August 1962, before starting treatment. Right, photograph taken on 16 July 1964, after 23 months' treatment, showing disappearance of xanthomata. 
Group $B$ comprised one patient only-a man aged 21 with eight months' history of xanthoma tuberosum on face, elbows, buttocks, and knees, and no other symptoms. This patient appeared to be a case of essential hyperlipaemia. Before treatment the serum cholesterol was $1,100 \mathrm{mg} . / 100 \mathrm{ml}$., and the total serum lipids were 8.5 g. $/ 100 \mathrm{ml}$. On treatment his serum cholesterol fell quickly to below $400 \mathrm{mg}$. and for 14 months thereafter fluctuated between 200 and $500 \mathrm{mg}$., but for the past six months it has been below $250 \mathrm{mg}$. After eight months' treatment his total serum lipids had fallen to $1.95 \mathrm{~g} . / 100 \mathrm{ml}$. In 15 months all xanthomata had completely disappeared (see Fig.).

Group $C$ consisted of one man only, a younger brother of the oldest patient in group A. This man, aged 42, had no xanthomata, but had suffered intermittent claudication for five years and had an impalpable left dorsalis pedis pulse. Before treatment his serum cholesterol was $600 \mathrm{mg} . / 100 \mathrm{ml}$. This fell promptly to $300 \mathrm{mg}$. and in two months was below 250 mg., and for the last 10 months has been below $200 \mathrm{mg}$. Before and after treatment his total serum lipids were $3.3 \mathrm{~g} . / 100 \mathrm{ml}$. and $1.8 \mathrm{~g}$. He claims some improvement in walking.

Group $D$ comprised one woman and one man with xanthelasma palpebrarum. The woman, aged 54, had noted xanthelasma for 10 years and had a myocardial infarction three years ago. She had since suffered from cardiac-effort pain. Her serum cholesterol before treatment was $680 \mathrm{mg} . / 100 \mathrm{ml}$. Since starting treatment it has varied between 400 and $500 \mathrm{mg}$. Before and after treatment her total serum lipids were $2.8 \mathrm{~g} . / 100 \mathrm{ml}$. and $1.65 \mathrm{~g}$. After two years' treatment there has been no change in the xanthelasma and no change in her symptoms. The man, aged 37, with xanthelasma palpebrarum of seven years' duration, had no other symptoms. Before treatment his serum cholesterol was $430 \mathrm{mg} . / 100 \mathrm{ml}$. On treatment it fell rapidly to below $300 \mathrm{mg}$. and has remained at this level. Before and after treatment his total blood lipids were $2.1 \mathrm{~g} . / 100 \mathrm{ml}$. and $4.3 \mathrm{~g}$. There has been no change in the xanthelasma during two years' treatment.

\section{Discussion}

It is thus clear that in the four patients with xanthoma tuberosum the administration of clofibrate with androsterone led to a striking fall in their serum cholesterol and in disappearance of the xanthomata. This is in striking contrast to the results recorded by Jepson and James (1963) in a similar group of patients. A similar fall in serum cholesterol was noted in the man with familial hypercholesterolaemia with intermittent limp but no xanthomata. There was a suggestion that symptoms were improved in two of the patients with intermittent claudication.

A much less marked effect on the serum cholesterol was observed in two patients with hypercholesterolaemia and xanthelasma palpebrarum, but there was no change in the xanthelasma.

Side-effects from the drug were slight. Four patients complained of some postprandial discomfort. There was a slight fall in the blood uric acid at the start of treatment, but this was not maintained. There was no rise in the serum glutamic pyruvic transaminase during treatment.

It now appears that clofibrate alone will have the same effect (Howard et al., 1963 ; Oliver, 1963), and it is proposed to continue treatment in these patients without the androsterone.

\section{Summary}

Clofibrate with androsterone (Atromid) in doses of $2 \mathrm{~g}$. daily for two years led to a fall in serum cholesterol and the disappearance of xanthoma tuberosum in four men with hypercholesterolaemia. In two patients with hypercholesterolaemia xanthelasma palpebrarum there was a less marked fall in serum cholesterol and no effect on the xanthelasma.

We are indebted to Imperial Chemical Industries Limited for supplies of Atromid, and to Dr. K. G. Green and Dr. C. C. Downie, of the I.C.I. medical department, for their interest and advice.

\section{REFERENCES}

Howard, R. P., Alaupovic, P., Brusco, O. J., and Furman, R. H. (1963). f. Atheroscler. Res., 3, 482.

Jepson, E. M., and James, D. C. O. (1963). Ibid., 3, 554.

Oliver, M. F. (1962). Lancet, 1, 1321. shoulders. He was standing on wet soil and was wearing hobnailed leather boots.

The lightning had the following effects: (1) It destroyed two rows of Japanese larch trees (these were about 20 yards (18 metres) away). (2) It scorched near-by ground and made two holes in the ground. (3) It burnt part of a near-by field of hay. (4) It knocked the husband and wife across the sheep-pen (a distance of $8 \mathrm{ft}$. ; $2.4 \mathrm{~m}$.). (5) It probably knocked the three people unconscious. When the husband picked himself up he found his wife and father lying on the ground. They recovered consciousness shortly afterwards, though the husband thought at first that his father was dead. (6) It almost completely destroyed the father's left boot and burnt his coat and shirt. He had extensive superficial burns of the back and the right leg. His left foot was made cold, cyanotic, pulseless, and anaesthetic to pinprick. (7) The woman felt that she had been struck on the back of the neck. She had a headache, which lasted for some hours. Her clothes were not burnt. She had a fern-leaf pattern superficial type of burn of entry at the back of the neck, on the right shoulder, and over the left mastoid region. Exit burns ran transversely across the buttocks. These burn marks disappeared within 24 hours.

The three people walked to a near-by farmhouse, where they were visited by Dr. H. G. Davies, who admitted the woman and 